\title{
Viral Suppression in Adult Nigerians in a Regional Antiretroviral Therapy Programme: A Cross Sectional Descriptive Study
}

\section{Elon Warnow Isaac1 (1), Ayomikun Ajani'2, Abubakar Joshua Difa ${ }^{3}$, John Tunde Aremu Oyeniyi Christianah Oluwaseun ${ }^{5}$, Muhammad Danlami Hassan ${ }^{6}$}

\author{
${ }^{1}$ Department of Paediatrics, College of Medical Sciences, Gombe State University, Gombe, Nigeria \\ ${ }^{2}$ Department of Paediatrics, Federal Teaching Hospital, Gombe, Nigeria \\ ${ }^{3}$ Department of Community Medicine, College of Medical Sciences Gombe State University, Gombe, Nigeria \\ ${ }^{4}$ Department of Medicine, Federal Teaching Hospital Gombe, Gombe, Nigeria \\ ${ }^{5}$ Infectious Diseases Training and Research Group Gombe, Gombe, Nigeria \\ ${ }^{6}$ Department of Molecular Microbiology, Federal Teaching Hospital Gombe, Gombe, Nigeria \\ Email: drwarnow@yahoo.com, ayomikuna2000@yahoo.com, joshdifa41@gmail.com, tundearemu007@outlook.com, \\ christyseunoye@yahoo.com, hafsat333@gmail.com
}

How to cite this paper: Isaac, E.W., Ajani, A., Difa, A.J., Aremu, J.T., Oluwaseun, O.C. and Hassan, M.D. (2021) Viral Suppression in Adult Nigerians in a Regional Antiretroviral Therapy Programme: A Cross Sectional Descriptive Study. World Journal of AIDS, 11, 1-14.

https://doi.org/10.4236/wja.2021.111001

Received: December 10, 2020

Accepted: March 12, 2021

Published: March 15, 2021

Copyright $\odot 2021$ by author(s) and Scientific Research Publishing Inc. This work is licensed under the Creative Commons Attribution International License (CC BY 4.0).

http://creativecommons.org/licenses/by/4.0/

(c) (i) Open Access

\begin{abstract}
Background: The adult ART (antiretroviral therapy) programme started in Nigeria in 2002. After many years of ART in the country, the National implementation plan for the scale up of viral load testing was launched in 2016. Viral load estimation is the most important indicator of ART response. Aim: To describe viral suppression in adults on the HIV ART programme Material \& methods: Viral load blood samples of 9450 adults on highly active antiretroviral therapy living with HIV from 4 states within Nigeria were analyzed for HIV RNA in Polymerase Chain Reaction laboratory of the Federal Teaching Hospital, Gombe between December 2017 and December 2019. Results: Males were 2577/9450 (27.3\%) and 6873 (72.7\%) females. Adults aged 26 - 45 years constituted $69.5 \%$ (6572). Viral load test was primarily routine in $96.3 \%$ (9098). ART was AZT/3TC/NVP in 52.5\% (4962); TDF/3TC/EFV in $46.3 \%$ (4375). 48.3\% (4568/9450) adults had received HAART for 1 - 5 years; $7.4 \%$ (699) for 6 months but $<1$ year; $37.6 \%$ (3551) 6 - 10 years and $6.7 \%$ (632) for $>10$ years. The most recent CD4 count before viral load request was $\geq 1000 / \mu \mathrm{L}$ in $6.5 \%$ (612) of adults; 500 - 999/ $\mu \mathrm{L}$ in $38.6 \%$ (3651); 350 - $499 \mu \mathrm{L}$ in $23.2 \%$ (2195) and $<350 \mu \mathrm{L}$ in $31.7 \%$ (2992). Viral load was $\geq 1000$ $\mathrm{c} / \mathrm{ml}$ in $22.9 \%(2167 / 9450)$ of adults. Viral load was $>1000 \mathrm{c} / \mathrm{ml}$ in $22.8 \%$ (587/2577) males and 23.0\% (1580/6873) females. Of adults aged $19-25$ years, $28.4 \%$ (211/743) had viral load $>1000 \mathrm{c} / \mathrm{ml} ; 23.5 \%$ (1544/6572); $20.0 \%$ (294/1473); $17.8 \%(93 / 523)$ and $18.0 \%(25 / 139)$ aged $26-45$ years, $46-55$
\end{abstract}


years; 56 - 65 years and $>65$ years also had viral load $>1000 \mathrm{c} / \mathrm{ml}$ (p value $<$ $0.001)$ Viral load was $>1000 \mathrm{c} / \mathrm{ml}$ in $26.0 \%$ (182/699) of adults on HAART for 6 months - 1 year and 21.3\% (975/4568) after receiving HAART for 1 - 5 years. $24.9 \%(885 / 3551)$ and $19.8 \%(125 / 632)$ adults had viral load $>1000$ $\mathrm{c} / \mathrm{ml}$ after receiving HAART for $6-10$ and $>10$ years respectively. (p value < 0.001 ) Conclusion: Over all viral suppression of $77 \%$ in our study is high but fell below the WHO threshold of $90 \%$. ART programme in Nigeria requires strengthening.

\section{Keywords}

Adult, ART, Viral Load $>1000$ c/ml, Nigeria

\section{Introduction}

The global scale-up of antiretroviral therapy (ART) under the public health approach of standardized and simplified regimens has registered significant gains, with increasing access to treatment for millions of people, and a reduction in new infections and HIV-associated morbidity and mortality and by end of 2019, 25.4 million people were receiving antiretroviral treatment worldwide [1]. Nigeria has the second largest HIV burden globally with an estimated 1,900,000 people living with the virus [2]. Of all adults aged 15 years and over living with HIV, $55 \%$ were on treatment, while only $35 \%$ of children aged 0 - 14 years living with HIV were on treatment in the country [3]. In 2018 in Nigeria: 67\% of people living with HIV knew their status; 53\% of people living with HIV were on treatment and $42 \%$ of people living with HIV were virally suppressed [3]. Nigeria therefore lags behind the ambitious treatment targets set by the Joint United Nations Programme on HIV/AIDS (UNAIDS), the 90-90-90 strategy by 2020 . This goal stipulates that by $2020,90 \%$ of all people living with HIV will know their HIV status; $90 \%$ of all people with diagnosed; HIV infection will receive sustained antiretroviral therapy; and $90 \%$ of all people receiving antiretroviral therapy will have viral suppression; as well as the elimination of AIDS as a public health threat by 2030 [4] [5].

Globally $59 \%$ of people living with HIV have undetectable levels of the virus and $47 \%$ are virally suppressed. In sub Saharan Africa, of the 25.7 million infected people, $60 \%$ are on ART and only $47 \%$ have achieved viral suppression [6].

World Health Organization recommended viral load testing as the preferred monitoring tool for diagnosing and confirming antiretroviral therapy failure. Plasma HIV RNA levels provide a direct measure of the efficacy of antiretroviral therapy (ART), predicting immunological and clinical outcomes and the risk of transmission [7].

Determination of virological suppression status of adults enrolled on ART is important as it allows for timely detection of treatment failures, identification of 
patients in need of more intensive adherence counseling and support and minimizes development of drug resistance and unnecessary switch to expensive and limited ART regimen options [8]. WHO guidelines recommend cross-sectional studies to monitor virological efficacy and resistance to ART, or the use of cohort studies to assess one of eight early warning indicators of HIV drug resistance: viral load suppression 12 months after ART initiation [9] [10].

Sustained viral suppression, which is the key goal of cART, facilitates restoration of the immune function and significantly reduces the risk of onward HIV transmission [11]. As the availability of viral load testing grows in developing countries, the percentage of patients with virological suppression can be an important measure of overall ART clinic and program success [12].

In sub Saharan Africa, proportions of virological success were highly variable [12] [13] and viral suppression rates declined during the first 4 years of ART [14].

In Nigeria, the viral load implementation strategy and plan was launched in 2016 [15] and the National Guideline on HIV prevention and treatment [16] recommends viral load determination six months after initiating cART and then annually if viral suppression was achieved. In individuals without viral suppression, adherence counseling support is intensified followed by another viral load testing so as to differentiate poor adherence from treatment failure. Treatment failure is defined by two viral load measurements $>1000 \mathrm{c} / \mathrm{ml}, 3$ months apart after the initial viral load determination and such individuals are switched to second-line ART [16].

ART for Nigerians living with HIV started in 2002 with 10,000 adults and by 2019, about a million people were receiving highly active antiretroviral treatment in the country [2]. The lack of routine viral load testing until 3 years ago meant suboptimal monitoring with risk for non-viral suppression and HIV drug resistance. Therefore, the aim of this study was to report viral load suppression among Adults living with HIV in a regional ART programme in Northern Nigeria.

\section{Methods}

\subsection{Study Design}

The study is descriptive cross sectional study conducted between 2017 and 2019 .

\subsection{Study Setting}

Blood samples for HIV Viral load estimation were collected from 9450 adults aged $>18$ years on HAART from several health facilities including primary, secondary and tertiary health institutions in 4 states in the North of Nigeria between 2017 and 2019. The following information: age, sex, date of HIV diagnosis, date of ART start, current ART regimen, first or second line ART, date of sample collection. Viral Load results were retrieved from the RNA PCR register from the Laboratory. The sample size was the number of adult in the ART pro- 
gramme in the reporting ART sites who had their samples sent to the PCR laboratory.

\subsection{Inclusion Criteria}

Adults with the following information age, sex, date of HIV diagnosis, date of ART start, current ART regimen; first or second line or third line, date of sample collection, together with a VL result were included. Adult was defined as age 19 years and above. Virological suppression (VS) was defined as viral load (VL) < 1000 RNA-copies/mL of blood plasma and virological non suppression (VNS) as $\mathrm{VL} \geq 1000$ RNA-copies/mL [15] [16]. Adults with incomplete data entry were excluded from this analysis.

\subsection{Viral Load Determination}

Viral load quantification of HIV-1 RNA was performed on plasma samples using COBAS 96 CAP//C TaqMan HIV-1 assay (Roche Diagnostics, Indianapolis, IN) at a limit of detection of 40 copies $/ \mathrm{mL}$. A protocol using $0.6 \mathrm{~mL}$ of plasma was used for RNA extraction. The lower limit of detection of the assay is $<40$ copies/mL of HIV-1 RNA.

The PCR laboratory, situated in the Federal Teaching Hospital Gombe, has been certified by the Federal Ministry of Health and the Pepfar CDC in Nigeria to determine HBV, HCV and HIV viral load.

Ethical clearance was received from the research and ethics committee of the Federal Teaching Hospital, Gombe.

Data was analyzed using Epi info version 3.5.1. All data were analysed with a statistical significance level set at $\mathrm{p}<0.05$. Frequencies, proportions, confidence interval were computed. Data were summarized using tables and figures. Hypothesis testing was performed using Pearson Chi Square and Chi Square as appropriate

\section{Results}

Table 1 shows that females constituted $72.7 \%$ and males $27.3 \%$ of those that had a HIV viral load test during the period. Males had $77.2 \%$ and females $77 \%$ viral suppression and distribution was statistically significant. Overall viral suppression in this sub regional adult ART programme was 77\% (Figure 1). Among all age groups, viral suppression increased with increasing age with $71.6 \%$ of the age group 19 - 25 years and $82 \%$ of the $>65$ years age group having viral load of $<1000 \mathrm{c} / \mathrm{ml}$. Viral non-suppression was highest, $28.4 \%$ in the $19-25$ year age group compared with $18 \%$ in the older age group. The distribution of viral suppression in the age groups was statiscally significant $(\mathrm{P}<0.001)$.

Adults on EFV and NVP based regimen had viral load suppression of between $73 \%$ and $75.6 \%$ while viral load $>1000 \mathrm{c} / \mathrm{ml}$ was reported in between $21.2 \%$ and $24.4 \%$ of these individuals; this finding was statistically significant (Table 1). Of the adults on ART, $97.2 \%$ and $0.3 \%$ were on first and third line respectively. Viral 
Table 1. Adults living with HIV and Viral suppression.

\begin{tabular}{|c|c|c|c|c|}
\hline Variable & Frequency & $<1000 \mathrm{cp} / \mathrm{ml}$ & $>1000 \mathrm{cp} / \mathrm{ml}$ & $\mathrm{X} 2$ \\
\hline \multicolumn{5}{|l|}{ Ages } \\
\hline $19-25 \mathrm{yrs}$ & $743(7.9)$ & $532(71.6)$ & $211(28.4)$ & \multirow[t]{5}{*}{$<0.001$} \\
\hline $26-45 \mathrm{yrs}$ & $6572(69.5)$ & $5028(76.5)$ & $1544(23.5)$ & \\
\hline $46-55 \mathrm{yrs}$ & $1473(15.6)$ & $1179(80.0)$ & $294(20.0)$ & \\
\hline $56-65 \mathrm{yrs}$ & $523(5.5)$ & $430(82.2)$ & $93(17.8)$ & \\
\hline$>65 \mathrm{yrs}$ & $139(1.5)$ & $114(82.0)$ & $25(18.0)$ & \\
\hline \multicolumn{5}{|l|}{ Sex } \\
\hline Males & $2577(27.3)$ & $1990(77.2)$ & $587(22.8)$ & \multirow[t]{2}{*}{0.829} \\
\hline Females & $6873(72.7)$ & $5293(77.0)$ & $1580(23.0)$ & \\
\hline \multicolumn{5}{|l|}{ ART Regimen } \\
\hline $\mathrm{AZT}+3 \mathrm{TC}+\mathrm{NVP}$ & $4962(52.5)$ & $3751(75.6)$ & $1211(24.4)$ & \multirow[t]{3}{*}{$<0.001$} \\
\hline $\mathrm{TDF}+3 \mathrm{TC}+\mathrm{EFV}$ & $4375(46.3)$ & $3449(78.8)$ & $926(21.2)$ & \\
\hline $\mathrm{TDF}+\mathrm{FTC}+\mathrm{EFV}$ & $113(1.2)$ & $83(73.5)$ & $30(26.5)$ & \\
\hline \multicolumn{5}{|l|}{ ART Type } \\
\hline 1st line & $9184(97.2)$ & $7103(77.4)$ & $2081(22.6)$ & \multirow[t]{3}{*}{$<0.001$} \\
\hline 2nd line & $239(2.5)$ & $164(68.6)$ & $75(31.4)$ & \\
\hline 3rd line & $27(0.3)$ & $16(59.3)$ & $11(40.7)$ & \\
\hline \multicolumn{5}{|l|}{ Duration on ART } \\
\hline $1 \mathrm{yr}$ & $699(7.4)$ & $517(74.0)$ & $182(26.0)$ & \multirow[t]{4}{*}{$<0.001$} \\
\hline $1-5 \mathrm{yrs}$ & $4568(48.3)$ & $3593(78.7)$ & $975(21.3)$ & \\
\hline $6-10 \mathrm{yrs}$ & $3551(37.6)$ & $2666(75.1)$ & $885(24.9)$ & \\
\hline$>10 \mathrm{yrs}$ & $632(6.7)$ & $507(80.2)$ & $125(19.8)$ & \\
\hline \multicolumn{5}{|l|}{ CD4 count } \\
\hline$<350$ & $2992(31.7)$ & $1963(65.6)$ & $1029(34.4)$ & \multirow[t]{4}{*}{$<0.001$} \\
\hline $350-499$ & $2195(23.2)$ & $1756(80.0)$ & $439(20.0)$ & \\
\hline $500-999$ & $3651(38.6)$ & $3051(83.6)$ & $600(16.4)$ & \\
\hline$>1000$ & $612(6.5)$ & $513(83.8)$ & $99(16.2)$ & \\
\hline \multicolumn{5}{|l|}{ Reason for request of viral load } \\
\hline Routine & $9098(96.3)$ & $7012(77.9)$ & $2086(22.1)$ & \multirow[t]{3}{*}{$<0.001$} \\
\hline Suspected clinical failure & $232(2.5)$ & $195(84.1)$ & $37(15.9)$ & \\
\hline Suspected immunological failure & $120(1.3)$ & $76(63.3)$ & $44(36.7)$ & \\
\hline \multicolumn{5}{|l|}{ ART Start Year } \\
\hline $2000-2004$ & $29(0.3)$ & $27(93.1)$ & $2(6.9)$ & \multirow[t]{4}{*}{0.052} \\
\hline $2005-2009$ & $2214(23.4)$ & $1674(75.6)$ & $540(24.4)$ & \\
\hline 2010-2014 & $4892(51.8)$ & $3797(77.6)$ & $1095(22.4)$ & \\
\hline $2015-2018$ & $2315(24.5)$ & $1785(77.1)$ & $530(22.9)$ & \\
\hline
\end{tabular}


load was $<1000 \mathrm{c} / \mathrm{ml}$ in $77.4 \%$ of those on first line and on second line was $68.6 \%$. Viral non-suppression was highest in adults on third line. The distribution of viral suppression and non-suppression was statiscally significant among ART type $\mathrm{P}<0.001$.

In relation to the duration of ART, $85.9 \%$ of adults had received cART for between one and ten years. Viral suppression increased with the duration on ART with $80.2 \%$ suppression after 10 years on ART; viral non-suppression was $26 \%$ in those adults on ART for one year compared to $19.8 \%$ in those on cART for 10 years (Figure 2). This distribution was statistically significant $\mathrm{P}<0.001$ (Table 1).

The higher the CD4 count the higher the viral suppression with $65.6 \%$ at CD4 count of 350 and $83.8 \%$ viral suppression at CD4 count of 1000 (Figure 3); Viral non-suppression was $16.2 \%$ at CD4 count of 1000 and $34.4 \%$ at CD4 count at $<350$ and this was statiscally significant $\mathrm{P}<0.001$.

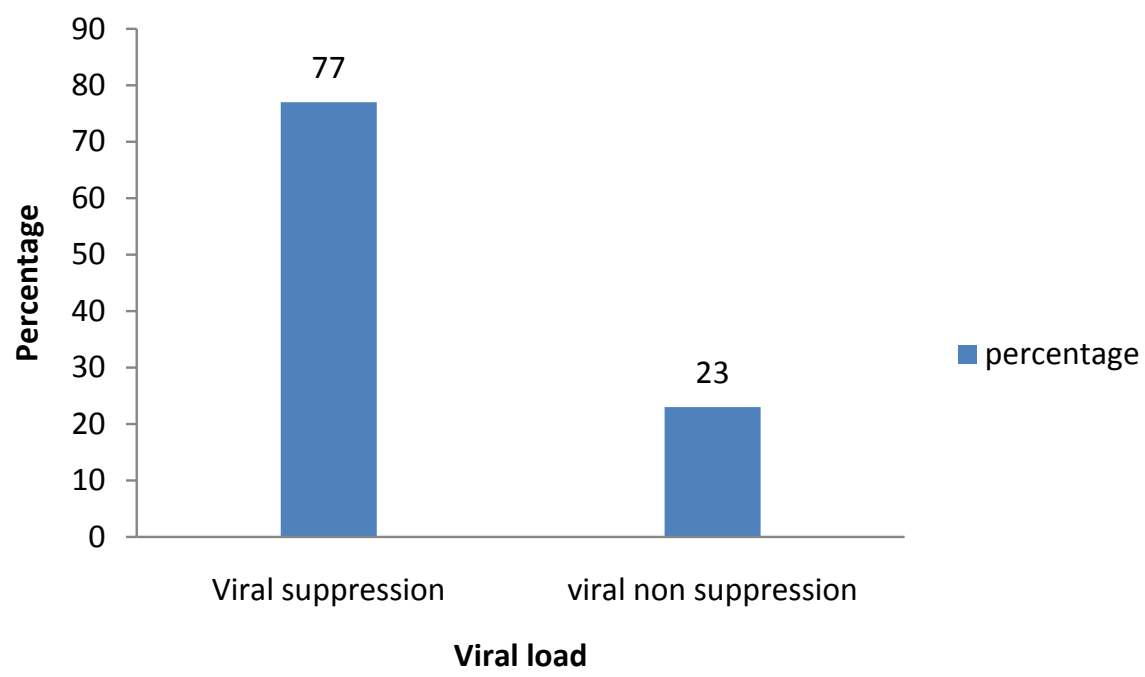

Figure 1. Viral load suppression status in Adults living with HIV/AIDS.

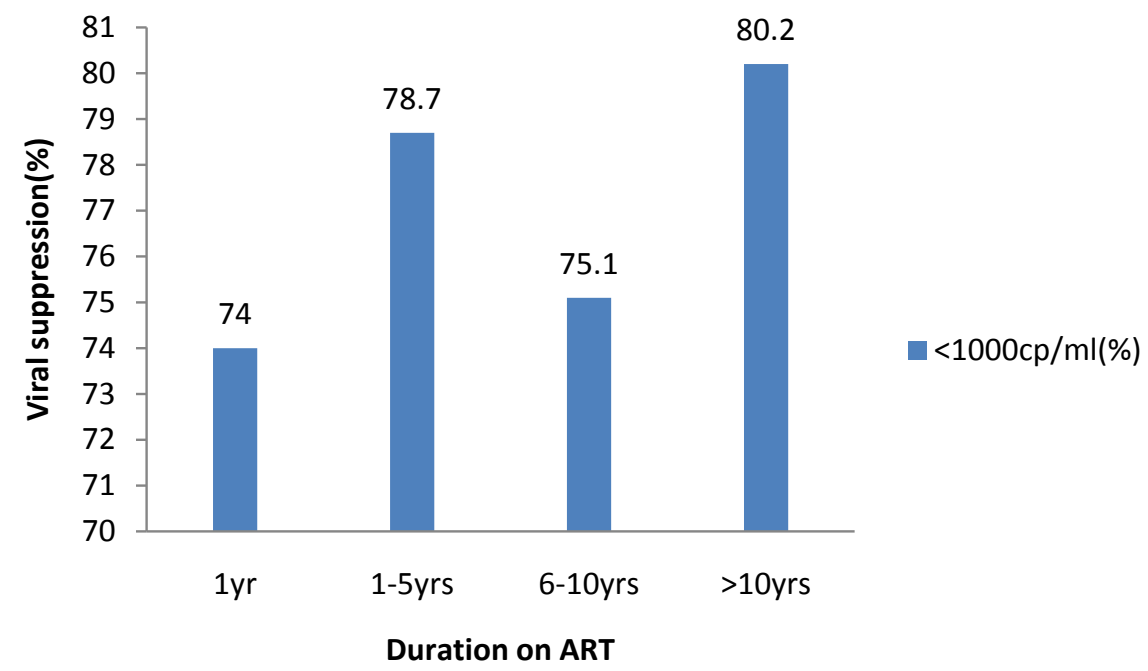

Figure 2. HIV Viral suppression rate and duration of ART in years in adults. 


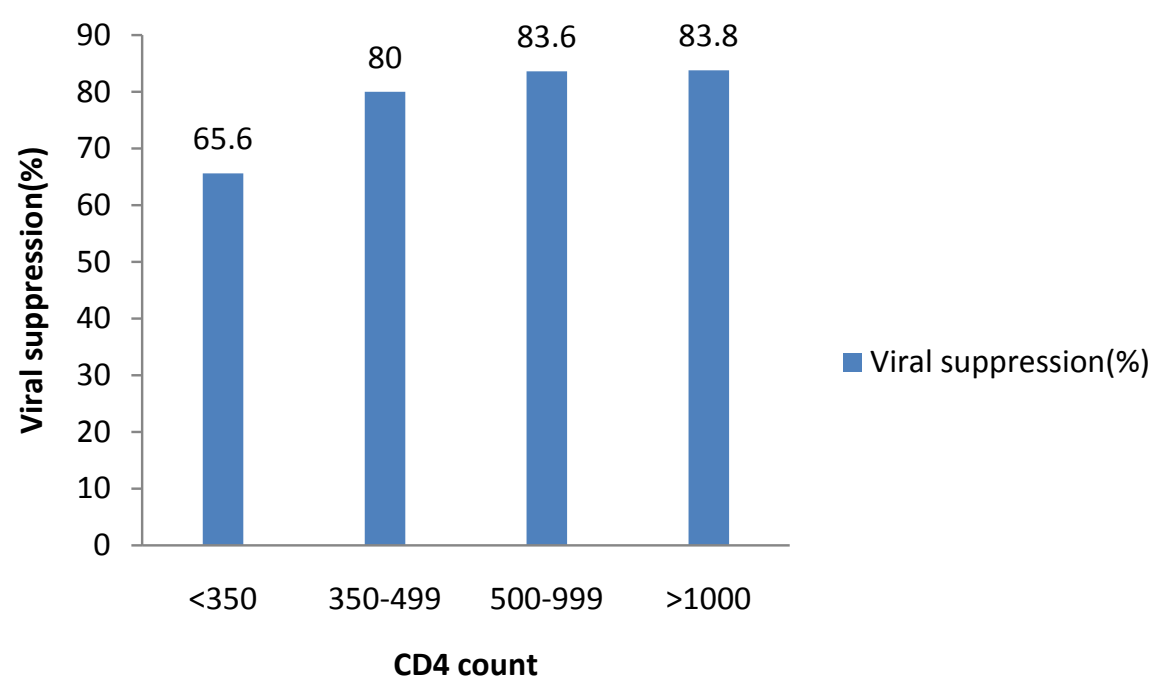

Figure 3. HIV Viral suppression rate and CD4 count in adults.

The reason for the request for a viral load test was suspected clinical failure in $2.5 \%$ and suspected immunological failure in $1.3 \%$ of adults on cART. Viral non-suppression occurred in $15.9 \%$ and $36.7 \%$ of those with suspected clinical and immunological failure respectively with statistically significant distribution. In relation to the year ART started, $85.3 \%$ of adults started cART between 2010 and 2018 (Table 1).

\section{Discussion}

Our study, determined viral load in a large number of adult Nigerians living with HIV in the national ART programme which started in 2002 [16]. Prior to 2017, ART monitoring was either clinical and /or immunological with viral load estimation for selected people living with HIV/AIDS on ART [17]. Therefore with no viral load determination as standard of care, thousands of Nigerians received NNRTI and NRTI based ART without virologic monitoring with risk for drug resistance and treatment failure. Routine regularly scheduled VL monitoring has the potential to preserve treatment options through early identification of those with non-suppression who might benefit from timely intensified adherence support to prevent treatment failure and the need for regimen changes [18] [19].

The overall viral suppression of $77 \%$ in adults in our study is higher than the $44.5 \%$ reported in adults at the national level in Nigeria [2]. In Nigeria there is wide variation in HIV prevalence between states and regions with subnational prevalence not representative [16]. While nationally representative viral suppression rates from Uganda, [20] Cameroon, [21] Kenya [22] and South Africa [23] are higher than the $44.5 \%$ reported in Nigeria, the viral suppression rates in all these countries in 2018 fall below the UNAIDS 90\% recommended viral suppression threshold. Subnational viral suppression rates from Ethiopia, [24] Cameroon, [25] South Africa [26] and Ghana [27] reported various suppression 
rates of $73 \%, 79 \%, 56.2 \%$ and $69 \%$ respectively. Earlier and recent systematic review of HIV viral suppression in low and middle income countries reported rates of $>80 \%$ but less than the $90 \%$ UNAIDS target for ART programmes [14] [28]. While substantial progress has been made in ART programmes in sub-Saharan, the differences in VS rates are generally related to study design, population characteristics, ART type and duration of treatment and suggest substantial differences in programme performances within and across countries [12] [29].

Females constituted two third of people living with HIV in our study and were equally as virally suppressed as males. Some studies [30] [31] [32] did not find an association between gender and virologic success or failures, other reports [33] [34] [35] [36] found that males were more likely to be virally none suppressed compared to females and as a consequence they have poor HIV immuno virologic and clinical outcomes compared to females.

Younger adults were more likely to achieve viral suppression than the older adults. This is similar to reports in sub-Saharan Africa [12] [20] [24] [37] and the USA [38].

Age transition challenges, Suboptimal adherence to cART, lack of psychosocial support, stigma and fear of disclosure, substance abuse and alcohol consumption are contributor factors to low viral suppression in adolescents and younger adults [24] [39] [40] [41].

There was little difference in viral suppression rate among the main first line ART regimen in this adult population of PLHIV in our study. This difference was also small in the virally non-suppressed adult PLHIV. While reports from Uganda [24] and Nepal [42] found an association between ART regimen and viral suppression, studies from Ethiopia [43] [44] and Cameroun [21] did not find any differences. These findings may be related to differences in sample size and programme performances [12] [29]. The proportion of adults on second and third line ART regimen in this large sub national programme is low. Reports from Ethiopia, [24] Cameroun, [25] Myammar, [45] South Africa [46] showed similar finding.

In Africa, a three year incidence of switching to second line was about $2 \%$, compared to $12 \%$ in Europe and about $30 \%$ in the United States [47]. Routine determination of viral suppression status and HIV Drug Resistance testing and surveillance in ART programmes enables early detection of treatment failure which is amenable to adherence counseling and or switching to second or third line ART regimen [8] [15] [16].

Viral suppression was higher in adults with higher CD4 count and the suppression rate increased with increasing CD4 count. This is similar to reports from Ethiopia, [24] Zimbabwe, [39] Cambodia [48] and Vietnam [49].

Low CD4 count might slow viral clearance. Sustained viral suppression, which is the key goal of cART, facilitates restoration of the immune function with resultant increase in CD4, the marker of this reconstitution [4].

Viral suppression of $74 \%$ after 12 months of ART in our study is similar to 
75\% from Cameroun, [25] and Cote d'Voire [50] lower than 86.4\% from Congo [51] but higher than 32\% from Uganda, [20] 69.2\% from Togo [52] and 62\% from Kenya [53].

A study from Cambodia [48] demonstrated decreasing viral suppression after 10 years of ART. Even though viral non suppression in our study is low, limited access to viral load and HIV drug resistance testing especially to NNRTI made failing and ineffective regimens being administered for many years [8] [9] [10].

Substantial progress has been made in routine viral load determination in ART programmes in sub Saharan African (96.3\%).

With the recent commencement of routine Viral load monitoring in Nigeria, a large proportion of adults monitored by clinical and immunologic means are now undergoing HIV RNA quantification as recommended in the National guideline [16]. The National guideline recommends initiation of ART as soon as possible preferably within two weeks of diagnosis of HIV infection.

\section{Conclusion}

Viral suppression in adults in this sub national ART programme in Northern Nigeria is high but below the WHO recommended threshold for viral suppression.

\section{Recommendations}

Viral load determination according to the National Guidelines for HIV prevention treatment and care and National implementation plan for scale-up of viral load testing in Nigeria should be implemented at all level of clinical care. HIV drug resistance surveillance is important in strengthening ART especially in a large HIV programme like that of Nigeria.

\section{Limitations}

This is the first viral load results in adults with HIV in an ART programme. We therefore could not establish treatment or virologic failure especially as we did not determine level of adherence and a second viral load.

\section{Authors' Contributions}

Elon Warnow Isaac: Conceived of the study and study design, developed the first manuscript draft and critically reviewed all drafts of the manuscript.

Dr. Abubakar Joshua Difa, Ajani Ayomikun and Ms. Oyeniyi Christianah Oluwaseun: Conducted quantitative data analysis and reviewed all drafts of the manuscript.

Dr. John Tunde Aremu and Mr. Muhammad Danlami Hassan: Reviewed and commented on data.

\section{Acknowledgements}

We acknowledge Hajiya Fatima Y Aliyu and Hajiya Zainab Danmalam of the 
data unit of paediatrics department for extracting the data. The management and staff of Centre for Integrated Health Partnership, fhi360 PEPFAR Implementing partners other non-government organisations and health care workers who are striving daily to provide quality HIV and AIDS care and treatment to children living with HIV/AIDS. We acknowledge the untiring effort of the Laboratory scientists and staff of the PCR Unit in the Federal Teaching Hospital Gombe.

\section{Conflicts of Interest}

Authors have no conflict of interest to declare.

\section{References}

[1] World Health Organization (2017) HIV Drug Resistance Report 2017. Licence: CC BY-NC-SA 3.0 IGO, UNAIDS Global HIV and AIDS Statistics, 2020 Fact Sheet. World Health Organization, Geneva.

[2] Nigeria HIV/AIDS Indicator and Impact Survey (2019) National Summary Sheet: Preliminary Findings.

[3] Joint United Nations Programme on HIV/AIDS (UNAIDS) (2018) Country Reports 2018-Nigeria. https://www.unaids.org/en/regionscountries/countries/nigeria

[4] Joint United Nations Programme on HIV/AIDS (UNAIDS) (2018) 90-90-90: An Ambitious Treatment Target to Help End the AIDS Epidemics.

[5] Joint United Nations Programme on HIV/AIDS (UNAIDS) (2017) Ending AIDS: Progress towards the 90-90-90 Targets.

[6] Joint United Nations Programme on HIV/AIDS (UNAIDS) (2018) Data 2018. UNAIDS, Geneva. www.unaids.org/en/resources/documents/2018/unaids-data-2018

[7] World Health Organization (2013) Consolidated Guidelines on the Use of Antiretroviral Drugs for Treating and Preventing HIV Infection: Recommendations for a Public Health Approach. World Health Organization, Geneva.

[8] World Health Organization (2006) HIV Drug Resistance. http://www.who.int/hiv/topics/drugresistance/en/

[9] World Health Organization (2014) Surveillance of HIV Drug Resistance in Adults Initiating Antiretroviral Therapy (Pre-Treatment HIV Drug Resistance) Concept Note.

http://apps.who.int/iris/bitstream/10665/112802/1/9789241507196_eng.pdf?ua=1

[10] World Health Organization (2016) Global Report on Early Warning Indicators of HIV Drug Resistance. http://www.who.int/hiv/pub/drugresistance/ewi-hivdr-2016/en/

[11] World Health Organization (2015) Guideline on When to Start Antiretroviral Therapy and on Pre-Exposure Prophylaxis for HIV. World Health Organization, Geneva. http://www.who.int/hiv/pub/guidelines/earlyrelease-arv/en

[12] Taieb, F., Madec, Y., Cournil, A. and Delaporte, E. (2017) Virological Success after 12 and 24 Months of Antiretroviral Therapy in Sub-Saharan Africa: Comparing Results of Trials, Cohorts and Cross-Sectional Studies Using a Systematic Review and Meta-Analysis. PLOS ONE, 12, e0174767. 
https://doi.org/10.1371/journal.pone.0174767

[13] Barth, R.E., van der Loeff, M.F., Schuurman, R., Hoepelman, A.I. and Wensing, A.M. (2010) Virological Follow-Up of Adult Patients in Antiretroviral Treatment Programmes in Sub-Saharan Africa: A Systematic Review. The Lancet Infectious Diseases, 10, 155-166. https://doi.org/10.1016/S1473-3099(09)70328-7

[14] Boender, T.S., Sigaloff, K.C., McMahon, J.H., Kiertiburanakul, S., Jordan, M.R., Barcarolo, J., et al. (2015) Long-Term Virological Outcomes of First Line Antiretroviral Therapy for HIV-1 in Low- and Middle-Income Countries: A Systematic Review and Meta-Analysis. Clinical Infectious Diseases, 61, 1453-1461. https://doi.org/10.1093/cid/civ556

[15] Federal Ministry of Health (2016) National Implementation Plan for Scale-Up of Viral Load Testing in Nigeria. Federal Ministry of Health, Nigeria.

[16] Federal Ministry of Health (2016) National Guidelines for HIV Prevention Treatment and Care. National AIDS and STIs Control Programme. Federal Ministry of Health, Abuja.

[17] Federal Ministry of Health (2010) National Guidelines for HIV and AIDS Treatment and Care in Adolescents and Adults. Federal Ministry of Health, Abuja.

[18] World Health Organization (2017) Global Action Plan on HIV Drug Resistance 2017-2021: 2018 Progress Report.

https://www.who.int/hiv/pub/drugresistance/hivdr-action-plan-2017-2021/en/

[19] Hamers, R.L., Schuurman, R., Sigaloff, K.C., Wallis, C.L., Kityo, C., Siwale, M., Mandaliya, K., Ive, P., Botes, M.E., Wellington, M. and Osibogun, A. (2012) Effect of Pretreatment HIV-1 Drug Resistance on Immunological, Virological, and Drug-Resistance Outcomes of First-Line Antiretroviral Treatment in Sub-Saharan Africa: A Multicenter Cohort Study. The Lancet Infectious Diseases, 12, 307-317. https://doi.org/10.1016/S1473-3099(11)70255-9

[20] Bulage, L., Ssewanyana, I., Nankabirwa, V., Nsubuga, F., Kihembo, C., Pande, G., et al. (2017) Factors Associated with Virological Non Suppression among HIV Positive Patients on Antiretroviral Therapy in Uganda, August 2014-July 2015. BMC Infectious Diseases, 17, Article No. 326. https://doi.org/10.1186/s12879-017-2428-3

[21] Tchouwa, G.T., Eymard-Duvernay, S., Cournil, A., Lamare, N., Serrano, L., Butel, C., et al. (2018) Nationwide Estimates of Viral Load Suppression and Acquired HIV Drug Resistance in Cameroon. Clinical Medicine, 1, 21-27. https://doi.org/10.1016/j.eclinm.2018.06.005

[22] Joint United Nations Programme on HIV/AIDS (UNAIDS) (2018) Country Reports 2018-Kenya. https://www.unaids.org/en/regionscountries/countries/kenya

[23] Joint United Nations Programme on HIV/AIDS (UNAIDS) (2018) Country Reports 2018-South Africa. https://www.unaids.org/en/regionscountries/countries/southafrica

[24] Desta, A.A., Woldearegay, T.W., Futwi, N., Gebrehiwot, G.T., Gebru, G.G., Berhe, A.A., et al. (2020) HIV Virological Non-Suppression and Factors Associated with Non-Suppression among Adolescents and Adults on Antiretroviral Therapy in Northern Ethiopia: A Retrospective Study. BMC Infectious Diseases, 20, Article No. 4. https://doi.org/10.1186/s12879-019-4732-6

[25] Fokam, J., Sosso, S.M., Yagai, B., Billong, S.C., Djubgang Mbadie, R.E., Kamgaing, Simo. R., et al. (2019) Viral Suppression in Adults, Adolescents and Children Receiving Antiretroviral Therapy in Cameroon: Adolescents at High Risk of Virological Failure in the Era of "Test and Treat". AIDS Research and Therapy, 16, Article No. 36. https://doi.org/10.1186/s12981-019-0252-0 
[26] Woldesenbet, S.A., Kufa, T., Barron, P., Chirombo, B.C., Cheyip, M., Ayalew, K., et al. (2020) Viral Suppression and Factors Associated with Failure to Achieve Viral Suppression among Pregnant Women in South Africa. AIDS, 34, 589-597.

[27] Lokpo, S.Y., Ofori-Attah, P., Ameke, L.S., Obirikorang, C., Orish, V.N., Kpene, G.E., et al. (2020) Viral Suppression and Its Associated Factors in HIV Patients on HAART: A Retrospective Study in the HO Municipality Ghana. AIDS Research and Treatment, 2020, Article ID: 9247451. https://doi.org/10.1155/2020/9247451

[28] McMahon, J.H., Elliott, J.H., Bertagnolio, S., Kubiak, R. and Jordan, M.R. (2013) Viral Suppression after 12 Months of Antiretroviral Therapy in Low- and Middle Income Countries: A Systematic Review. Bulletin of the World Health Organization, 91, 377-385E. https://doi.org/10.2471/BLT.12.112946

[29] Arpadi, S.M., Shiau, S., Gusmao, E.P.D. and Violari, A. (2017) Routine Viral Load Monitoring in HIV-Infected Infants and Children in Low- and Middle-Income Countries: Challenges and Opportunities. COMMENTARY. Journal of the International AIDS Society, 20, e2500. https://doi.org/10.1002/jia2.25001

[30] Cornell, M., Schomaker, M., Garone, D.B., Giddy, J., Hoffmann, C.J., Lessells, R., et al. (2012) Gender Differences in Survival among Adult Patients Starting Antiretroviral Therapy in South Africa: A Multicentre Cohort Study. PLoS Medicine, 9, e1001304. https://doi.org/10.1371/journal.pmed.1001304

[31] De Beaudrap, P., Thiam, M., Diouf, A., Toure-Kane, C., Ngom-Gueye, N.F., Vidal, N., et al. (2013) Risk of Virological Failure and Drug Resistance during First and Second-Line Antiretroviral Therapy in a 10-Year Cohort in Senegal: Results from the ANRS 1215 Cohort. Journal of Acquired Immune Deficiency Syndromes, 62, 381-387. https://doi.org/10.1097/QAI.0b013e31827a2a7a

[32] Datay, M.I., Boulle, A., Mant, D. and Yudkin, P. (2010) Associations with Virologic Treatment Failure in Adults on Antiretroviral Therapy in South Africa. Journal of Acquired Immune Deficiency Syndromes, 54, 489-495. https://doi.org/10.1097/QAI.0b013e3181d91788

[33] Abioye, A.I., Soipe, A.I., Salako, A.A., Odesanya, M.O., Okuneye, T.A., Abioye, A.I., et al. (2015) Are There Differences in Disease Progression and Mortality among Male and Female HIV Patients on Antiretroviral Therapy? A Meta-Analysis of Observational Cohorts. AIDS Care, 27, 1468-1486. https://doi.org/10.1080/09540121.2015.1114994

[34] Beckham, S.W., Beyrer, C., Luckow, P., Doherty, M., Negussie, E.K. and Baral, S.D. (2016) Marked Sex Differences in All-Cause Mortality on Antiretroviral Therapy in Low- and Middle-Income Countries: A Systematic Review and Meta-Analysis. Journal of the International AIDS Society, 19, Article ID: 21106. https://doi.org/10.7448/IAS.19.1.21106

[35] Penot, P., He'ma, A., Bado, G., Kabore, F., Sore, I., Sombie, D., et al. (2014) The Vulnerability of Men to Virologic Failure during Antiretroviral Therapy in a Public Routine Clinic in Burkina Faso. Journal of the International AIDS Society, 17, Article ID: 18646. https://doi.org/10.7448/IAS.17.1.18646

[36] Novelli, S., Delobel, P., Bouchaud, O., Avettand-Fenoel, V., Fialaire, P., Cabié, A., et al. (2020) Enhanced Immunovirological Response in Women Compared to Men after Antiretroviral Therapy Initiation during Acute and Early HIV-1 Infection: Results from a Longitudinal Study in the French ANRS Primo Cohort. Journal of the International AIDS Society, 23, e25485. https://doi.org/10.1002/jia2.25485

[37] Ayele, G., Tessema, B., Amsalu, A., Ferede, G. and Yismaw, G. (2018) Prevalence and Associated Factors of Treatment Failure among HIV/AIDS Patients on HAART 
Attending University of Gondar Referral Hospital Northwest Ethiopia. BMC Immunology, 19, Article No. 37. https://doi.org/10.1186/s12865-018-0278-4

[38] Yehia, B.R., Rebeiro, P., Althoff, K.N., Agwu, A.L., Horberg, M.A., Samji, H., et al. (2015) Impact of Age on Retention in Care and Viral Suppression. Journal of Acquired Immune Deficiency Syndromes, 68, 413-419. https://doi.org/10.1097/QAI.0000000000000489

[39] Sithole, Z., Mbizvo, E., Chonzi, P., Mungati, M., Juru, T.P., Shambira, G., et al. (2018) Virological Failure among Adolescents on ART, Harare City, 2017-A Case-Control Study. BMC Infectious Diseases, 18, Article No. 469. https://doi.org/10.1186/s12879-018-3372-6

[40] Katz, I.T., Ryu, A.E., Onuegbu, A.G., Psaros, C., Weiser, S.D., Bangsberg, D.R., et al. (2013) Impact of HIV-Related Stigma on Treatment Adherence: Systematic Review and Meta-Synthesis. Journal of the International AIDS Society, 16, Article ID: 18640. https://doi.org/10.7448/IAS.16.3.18640

[41] Peltzer, K. and Pengpid, S. (2013) Socioeconomic Factors in Adherence to HIV Therapy in Low- and Middle-Income Countries. Journal of Health, Population and Nutrition, 31, 150-170. https://doi.org/10.3329/jhpn.v31i2.16379

[42] Kiweewa, F., Esber, A., Musingye, E., Reed, D., Crowell, T.A., Cham, F., et al. (2019) HIV Virologic Failure and Its Predictors among HIV-Infected Adults on Antiretroviral Therapy in the African Cohort Study. PLoS ONE, 14, e0211344. https://doi.org/10.1371/journal.pone.0211344

[43] Bayu, B., Tariku, A., Bulti, A.B., Habitu, Y.A., Derso, T. and Teshome, D.F. (2017) Determinants of Virological Failure among Patients on Highly Active Antiretroviral Therapy in University of Gondar Referral Hospital, Northwest Ethiopia: A Case-Control Study. HIVI AIDS-Research and Palliative Care, 9, 153-159. https://doi.org/10.2147/HIV.S139516

[44] Hailu, G.G., Hagos, D.G., Hagos, A.K., Wasihun, A.G. and Dejene, T.A. (2018) Virological and Immunological Failure of HAART and Associated Risk Factors among Adults and Adolescents in the Tigray Region of Northern Ethiopia. PLoS ONE, 13, e0196259. https://doi.org/10.1371/journal.pone.0196259

[45] Kyaw, N.T.T., Harries, A.D., Kumar, A.M.V., Oo, M.M., Kyaw, K.W.Y., Win, T., et al. (2017) High Rate of Virological Failure and Low Rate of Switching to Second-Line Treatment among Adolescents and Adults Living with HIV on First Line ART in Myanmar, 2005-2015. PLoS ONE, 12, e0171780.

https://doi.org/10.1371/journal.pone.0171780

[46] Evans, D., Hirasen, K., Berhanu, R., Malete, G., Ive, P., Spencer, D., et al. (2018) Predictors of Switch to and Early Outcomes on Third-Line Antiretroviral Therapy at a Large Public-Sector Clinic in Johannesburg, South Africa. AIDS Research and Therapy, 15, Article No. 10. https://doi.org/10.1186/s12981-018-0196-9

[47] The Collaborative Initiative for Paediatric HIV Education and Research (CIPHER) Global Cohort Collaboration (2019) Incidence of Switching to Second Line Antiretroviral Therapy and Associated Factors in Children with HIV: An International Cohort Collaboration. Lancet HIV, 6, E105-E115. https://doi.org/10.1016/S2352-3018(18)30319-9

[48] Chhim, K., Mburu, G., Tuot, S., Sopha, R., Khol, V., Chhoun, P., et al. (2018) Factors Associated with Viral Non-Suppression among adolescents Living with HIV in Cambodia: A Cross-Sectional Study. AIDS Research and Therapy, 15, Article No. 20. https://doi.org/10.1186/s12981-018-0205-Z

[49] Rangoran, S., Colby, D.J., Truong, G.L., Bui, D.D., Nguyen, H.H., Tou, P.B., et al. 
(2016) Factors Associated with HIV Viral Load Suppression on Antiretroviral Therapy in Vietnam. Journal of Virus Eradication, 2, 94-101.

https://doi.org/10.1016/S2055-6640(20)30466-0

[50] Messou, E., Chaix, M.L., Gabillard, D., Minga, A., Losina, E., Yapo, V., et al. (2011) Association between Medication Possession Ratio, Virologic Failure and Drug Resistance in HIV-1-Infected Adults on Antiretroviral Therapy in Cote d'Ivoire. Journal of Acquired Immune Deficiency Syndromes, 56, 356-364.

https://doi.org/10.1097/QAI.0b013e3182084b5a

[51] Muwonga, J., Edidi, S., Butel, C., Vidal, N., Monleau, M., Okenge, A., et al. (2011) Resistance to Antiretroviral Drugs in Treated and Drug-Naive Patients in the Democratic Republic of Congo. Journal of Acquired Immune Deficiency Syndromes, 57, S27-S33. https://doi.org/10.1097/QAI.0b013e31821f596c

[52] Dagnra, A.Y., Vidal, N., Mensah, A., Patassi, A., Aho, K., Salou, M., et al. (2011) High Prevalence of HIV-1 Drug Resistance among Patients on First-Line Antiretroviral Treatment in Lomé, Togo. Journal of the International AIDS Society, 14, 30. https://doi.org/10.1186/1758-2652-14-30

[53] Humphrey, J.M., Genberg, B.L., Keter, A., Musick, B., Apondi, E., Gardner, A., Hogan, J.W. and Wools-Kaloustian, K. (2019) Viral Suppression among Children and Their Caregivers Living with HIV in Western Kenya. Journal of the International AIDS Society, 22, e2527. https://doi.org/10.1002/jia2.25272

\section{Abbreviations/Acronyms}

ART: Anti-retroviral therapy

AZT: Zidovudine

cART: Combination Anti-retroviral Therapy

EFV: Efavirenz

HIV: Human Immunodeficiency vaccine

3TC: Lamivudine

NRTI: Nucleoside reverse transcriptase inhibitors

NNRTI: Non-nucleotide reverse transcriptase inhibitors

NVP: Nevirapine

PLHIV: People living with HIV

RNA: Ribonucleic acid

TDF: Tenofovir

UNAIDS: Joint United Nations Programme on HIV/AIDS

VS: Viral Suppression 